\title{
Mixture model applied to the development of polymeric fibre diaphragms
}

\author{
Celso Fidelis de Moura Junior ${ }^{1}$, Raquel Araújo Nunes ${ }^{2}$, \\ Rafael Teles Cruz Silva ${ }^{1}$, Hélio de Lucena Lira ${ }^{2}$, \\ Carlos Thiago Cândido Cunha ${ }^{2}$, Eudésio Oliveira Vilar ${ }^{1}$
}

\footnotetext{
${ }^{1}$ Universidade Federal de Campina Grande, Laboratório de Engenharia Eletroquímica (LEEq), Rua Aprígio Veloso, 882, CEP: 58109-970, Campina Grande, PB, Brasil.

${ }^{2}$ Universidade Federal de Campina Grande, Departamento de Engenharia de Materiais, Rua Aprígio Veloso, 882, 58109970, Campina Grande, PB, Brasil

e-mail: fideliscelso@gmail.com, rafaelteles090@gmail.com, oliveiravilar@gmail.com, nunesraquel21@gmail.com, carlos.thiago@ufcg.edu.br, hélio.lira@ufcg.edu.br
}

\begin{abstract}
The extraction and use of asbestos have been banned around the world because of its damage effects to the human health, it leads to studies of new materials in order to replace asbestos in several processes. The objective of this paper is to apply the simplex lattice planning and the mixture model in the manufacture of diaphragms. A mixture model was performed according to the simplex lattice, using four polyethylene microfibers (MF's) of different lengths, with 1st degree polynomial, adding inner and central points and a repetition, generating 18 mixtures. The results showed that microfibers of greater length have a greater influence on the diaphragms properties, presenting a more significant result on permeability. From the linear regression it was possible to estimate a mathematical model combining the three properties of the diaphragm, presenting a correlation of $92.12 \%$.
\end{abstract}

Keywords: Simplex lattice, model, polymeric diaphragm, microfibers.

\section{INTRODUCTION}

Caustic soda $(\mathrm{NaOH})$ and chlorine $\left(\mathrm{Cl}_{2}\right)$ are basic raw materials for the world chemical industry. More than $50 \%$ of sales in the sector depend, at some stage of their production process, of these inputs [1].

The process of chlorine-soda production by electrochemistry occurs through the passage of an electric current through the brine where, by electrolysis, there is the formation of chlorine gas, caustic soda and hydrogen gas.

Currently, three electrolysis processes are the most widely used industrially: mercury, diaphragm and membrane. According to the report presented by the Brazilian association of the industry of alkalis, chlorine and derivatives - Abiclor, diaphragm cell technology was the most used by this sector in brazil in 2014, corresponding to $62 \%$ of the installed capacity (9\% of diaphragms without asbestos and $53 \%$ with chrysotile). In 2017, diaphragm technology corresponded to $13.9 \%$ of the world chlorine-soda production [2].

The first cells with asbestos diaphragm were successful between 1928 and 1948 [3-5]. However, since 1970, researcher have been conducted to develop asbestos-free diaphragms, mainly due to the prevailing laws that objecting to their banishment. The main diaphragms that have achieved commercial purposes are basically constituted of fibrous polymeric material, resistant to the corrosive atmosphere of the cell, the example of perfluorinated polymers such as polytetrafluorethylene (PTFE) [3, 6] companies such as Eltech Systems and PPG Industries have made significant progress in the development of new diaphragms. Eltech has developed the called Polyramix (PMX) with some superior properties to asbestos, while PPG Industries developed the Tephram, a diaphragm formed by PTFE fibers, microfibers, Nafion ${ }^{\circledR}$ among other constituents [3]. The PMX is produced from the physical combination of metallic oxide particles and a fluorocarbon resin, presenting a branched, irregular and flexible structure, with lengths of 1-7 mm and diameter of 10-100 $\mu \mathrm{m}$ [7].

In beginning of the 90's, rhone poulenc chemie developed the so-called "embedded pre-cathode diaphragms". These consist of two layers, both porous deposited in the cathode. The first layer, the preform, 
consists of a conductive fibrous material, an electrocatalyst (e.g. Raney Ni), a pore-forming agent and a fluoropolymer. The second layer is a ptfe-based composition with a pore-forming agent [8].

Decades have sought to optimize diaphragms and replace asbestos as raw material of the separators in the electrolysis of brine. It is remarkable that over time several advances have been achieved, such as the insertion of polytetrafluoroethylene fibers, and inorganic oxides. Although the environment in the electrolytic cell is quite aggressive, there is a range of other materials that can be employed such as polymeric fibers and clays [9].

In brazil in the mid-2004, pioneering studies were looking for another type of material that was not perfluorated in order to minimize costs while maintaining satisfactory performance. According to [10], which studied the manufacture of diaphragms from the mixture of asbestos and polyethylene fibers, the results were promising by numerous advantages, such as the high chemical and mechanical resistance. In the work of [9], polyethylene fibers and clays diaphragms showed excellent results regarding permeability and resistivity when compared to data obtained for asbestos diaphragms.

Based on this information, the aim of this study is to relate the materials used in the manufacture of diaphragms with their physical properties, based in mixing model and using method of simplex lattice in order to propose mathematical models that explain these relationships.

\section{MATERIALS AND METHODS}

In this work, four types of commercial ultra-high-molecular-weight polyethylene (UHMWPE) microfibers (MF's) (table 1), with different lengths were used, to manufacture diaphragms. All microfibers were selected according to their chemical and stability characteristics, and all resistant to the operating conditions of the electrochemical reactor ( $\mathrm{pH}$ between 2 and 13 and temperatures between $50{ }^{\circ} \mathrm{C}$ and $80{ }^{\circ} \mathrm{C}$ ) as well as to high concentrations of chlorine and alkali, as shown by [11] and on described on the fabrics technical data sheet.

Table 1: UHMWPE microfiber used in the manufacture of diaphragms.

\begin{tabular}{c|c|c}
\hline MICROFIBER (MF) & LENGTH (MM) & AVARAGE DIAMETER $(\boldsymbol{\mu m})$ \\
\hline MF50 & 0.1 & 5 \\
\hline MF02 & 0.6 & 15 \\
\hline MF05 & 0.9 & 1.2 \\
\hline MF78 & 1.6 & 1.2 \\
\hline
\end{tabular}

Kelcocrete, provide by CpKelco, was used as a thickening agent and Atagel, provide by BASF was used as a porosity control agent, mineral brine at room temperature with a $\mathrm{NaCl}$ concentration around 320.0 $\mathrm{g} / \mathrm{L}$ at room temperature was used.

\subsection{Preparation and characterization of diaphragms}

The methodology used in the preparation of the diaphragms was based on the work developed by [9]. The diaphragms were characterized as to the thickness, permeability and resistivity. The resistivity, $\mathrm{N}_{\operatorname{mac}}$, was based on the work carried out by [12].

\subsection{Simplex Lattice Project}

The simplex lattice is a mechanism for optimizing the proportions of ingredients in mixing projects, by combining mathematical theory, statistical analysis and experimental design [13]. conditions:

The experimental space of a mixture with $\mathrm{p}$ components is reduced to a simplex region limited by the

$$
\begin{aligned}
& x_{i} \geq 0, \quad 1 \leq i \leq p \\
& \sum_{i=1}^{p} x_{i}=1
\end{aligned}
$$

where $x_{i}$ represents the proportion of the $i$-th component. This equation removes a degree of freedom from the proportions. 
The experimental space, which contains the p components of the mixture, can be geometrically represented by the interior and boundaries (vertex, edges, faces) of a regular simplex (p-1) - dimension [14, 15]. Fig. 1 [16] represents experimental spaces of a simplex.

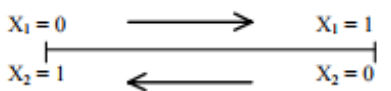

(a)

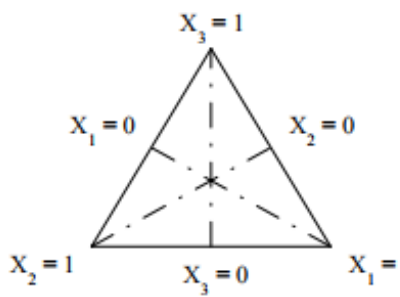

(b)

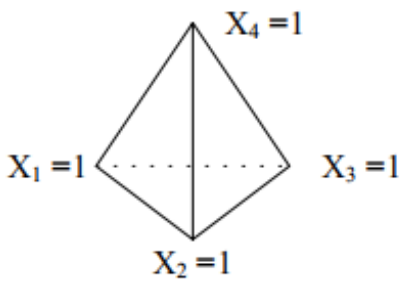

(c)

Figure 1: Experimental space for: (a) two, (b) three and (c) four components.

According to 4 MF's the simplex lattice mixture planning method was used with a $1^{\text {st }}$ degree polynomial, added interior points, a central point and a repetition. The method generated 18 assays, where each assay corresponds to a diaphragm. In Table 2, the experiments generated with the respective proportions are shown.

Table 2: Experimental Planning type Simplex-Lattice for 4 components.

\begin{tabular}{c|c|c|c|l|l|l|l|l}
\hline & \multicolumn{4}{|c|}{ COMPONENTS (g) } & \multicolumn{4}{c}{ PSEUDO-COMPONENT } \\
\hline ESSAY & MF50 & MF05 & MF02 & \multicolumn{1}{|c|}{ MF78 } & \multicolumn{1}{|c}{$\mathbf{X}_{1}$} & \multicolumn{1}{|c}{$\mathbf{X}_{2}$} & \multicolumn{1}{|c}{$\mathbf{X}_{3}$} & $\mathbf{X}_{4}$ \\
\hline 1 & 1.6 & 0 & 0 & 0 & 1.000 & 0 & 0 & 0 \\
\hline 2 & 0 & 1.6 & 0 & 0 & 0 & 1.000 & 0 & 0 \\
\hline 3 & 0 & 0 & 1.6 & 0 & 0 & 0 & 1.000 & 0 \\
\hline 4 & 0 & 0 & 0 & 1.6 & 0 & 0 & 0 & 1.000 \\
\hline 5 & 1.0 & 0.2 & 0.2 & 0.2 & 0.625 & 0.125 & 0.125 & 0.125 \\
\hline 6 & 0.2 & 1.0 & 0.2 & 0.2 & 0.125 & 0.625 & 0.125 & 0.125 \\
\hline 7 & 0.2 & 0.2 & 1.0 & 0.2 & 0.125 & 0.125 & 0.625 & 0.125 \\
\hline 8 & 0.2 & 0.2 & 0.2 & 1.0 & 0.125 & 0.125 & 0.125 & 0.625 \\
\hline 9 & 0.4 & 0.4 & 0.4 & 0.4 & 0.250 & 0.250 & 0.250 & 0.250 \\
\hline 10 & 1.6 & 0 & 0 & 0 & 1.000 & 0 & 0 & 0 \\
\hline 11 & 0 & 1.6 & 0 & 0 & 0 & 1.000 & 0 & 0 \\
\hline 12 & 0 & 0 & 1.6 & 0 & 0 & 0 & 1.000 & 0 \\
\hline 13 & 0 & 0 & 0 & 1.6 & 0 & 0 & 0 & 1.000 \\
\hline 14 & 1.0 & 0.2 & 0.2 & 0.2 & 0.625 & 0.125 & 0.125 & 0.125 \\
\hline 15 & 0.2 & 1.0 & 0.2 & 0.2 & 0.125 & 0.625 & 0.125 & 0.125 \\
\hline 16 & 0.2 & 0.2 & 1.0 & 0.2 & 0.125 & 0.125 & 0.625 & 0.125 \\
\hline 17 & 0.2 & 0.2 & 0.2 & 1.0 & 0.125 & 0.125 & 0.125 & 0.625 \\
\hline 18 & 0.4 & 0.4 & 0.4 & 0.4 & 0.250 & 0.250 & 0.250 & 0.250 \\
\hline
\end{tabular}

\subsection{Mathematical model of mixtures}

To evaluate the properties of the diaphragms, the special linear, quadratic and cubic models proposed by [17] were tested and represented by equations 1,2 and 3 , respective

$Y(\beta, x)=\sum_{i=1}^{q} \beta_{i} x_{i}$

$Y(\beta, x)=\sum_{i=1}^{q} \beta_{i} x_{i}+\sum \sum_{i<j}^{q} \beta_{i j} x_{i} x_{j}$

(2) 
$Y(\beta, x)=\sum_{i=1}^{q} \beta_{i} x_{i}+\sum \sum_{i<j}^{q} \beta_{i j} x_{i} x_{j}+\sum \sum \sum_{i<j<k}^{q} \beta_{i j k} x_{i} x_{j} x_{k}$

Where $\mathrm{y}(\beta, \mathrm{x})$ represents the response function and $\beta$ is the interaction coefficient. The variables $\mathrm{x}_{\mathrm{i}}, \mathrm{x}_{\mathrm{j}}$ and $\mathrm{x}_{\mathrm{k}}$ represent the independent variables of the process.

Using the STATISTICA software (version 10, doe Statsoft inc. Tulsa, USA), the models were evaluated based on the analysis of variance (ANOVA), and the interaction coefficients were analyzed through the tukey test. Through this method, the pareto charts were obtained, and the significance of the coefficients of each proposed model was evaluated.

\section{RESULTS AND DISCUSSION}

For the diaphragm to be considered ideally applicable in the production of chlorine-soda, it must present a low value of thickness, permeability and resistivity along with resistance to the severe conditions of the operation of the electrochemical cell.

For a diaphragm to have a good result it must be thin, as thickness is directly linked to cell voltage and energy consumption, and it must present a low permeability because, according to [10], permeability is a determining parameter of the migration of anionic species. Anionic migration causes the reverse migration of hydroxyls from the cathodic to the anodic compartment, forming sodium hypochlorite that increases consumption generated chlorine, thus decreasing the efficiency of the electrolysis process [18]. Lastly, a diaphragm must have a low $\mathrm{N}_{\text {mac }}$ value, as this parameter characterizes the resistivity of the diaphragm for the energy efficiency of the process, where, the lower the separator resistivity, the lower the $\mathrm{N}_{\operatorname{mac}}$ and the lower the overall energy consumption [19].

Table 3 shows the mean values of the thickness and permeability as well as the resistivity responses of the diaphragms developed from the experimental mix planning.

Table 3: Experimental values obtained from the characterization of the diaphragms according to the simplex-lattice planning.

\begin{tabular}{|c|c|c|c|c|c|c|c|}
\hline ESSAY & $\begin{array}{c}\text { MF50 } \\
(\%)\end{array}$ & $\begin{array}{c}\text { MF05 } \\
(\%)\end{array}$ & $\begin{array}{c}\text { MF2 } \\
(\%)\end{array}$ & $\begin{array}{c}\text { MF78 } \\
(\%)\end{array}$ & $\mathrm{L}(\mathrm{cm})$ & $\mathrm{K} \times 10^{-8}\left(\mathrm{~cm}^{2}\right)$ & $N_{m a c}$ \\
\hline 1 & 100 & 0 & 0 & 0 & 0.242 & 0.731 & 1.12 \\
\hline 2 & 0 & 100 & 0 & 0 & 0.178 & 0.847 & 1.14 \\
\hline 3 & 0 & 0 & 100 & 0 & 0.505 & 5.800 & 1.16 \\
\hline 4 & 0 & 0 & 0 & 100 & 0.427 & 13.700 & 1.35 \\
\hline 5 & 62.5 & 12.5 & 12.5 & 12.5 & 0.356 & 3.860 & 1.16 \\
\hline 6 & 12.5 & 62.5 & 12.5 & 12.5 & 0.286 & 5.050 & 1.21 \\
\hline 7 & 12.5 & 12.5 & 62.5 & 12.5 & 0.228 & 0.699 & 1.15 \\
\hline 8 & 12.5 & 12.5 & 12.5 & 62.5 & 0.277 & 7.350 & 1.23 \\
\hline 9 & 25 & 25 & 25 & 25 & 0.248 & 5.380 & 1.22 \\
\hline 10 & 100 & 0 & 0 & 0 & 0.269 & 0.710 & 1.13 \\
\hline 11 & 0 & 100 & 0 & 0 & 0.259 & 0.867 & 1.12 \\
\hline 12 & 0 & 0 & 100 & 0 & 0.286 & 5.710 & 1.18 \\
\hline 13 & 0 & 0 & 0 & 100 & 0.443 & 14.100 & 1.39 \\
\hline 14 & 62.5 & 12.5 & 12.5 & 12.5 & 0.362 & 3.890 & 1.17 \\
\hline 15 & 12.5 & 62.5 & 12.5 & 12.5 & 0.304 & 5.000 & 1.19 \\
\hline 16 & 12.5 & 12.5 & 62.5 & 12.5 & 0.228 & 0.663 & 1.12 \\
\hline 17 & 12.5 & 12.5 & 12.5 & 62.5 & 0.315 & 7.980 & 1.20 \\
\hline 18 & 25 & 25 & 25 & 25 & 0.294 & 5.170 & 1.22 \\
\hline
\end{tabular}


Using the experimental proportions and the response variables (thickness, permeability and resistivity) from the construction of the simplex-lattice design, the analysis of variance was used to define and evaluate the regression model and the significance of the independent factors. For the analysis, a statistical significance level of $5 \%$ was chosen, where, the model and factors are significant when they present a p-value less than or equal to $5 \%$.

Table 4 presents the equations generated for the special cubic model and the ANOVA results for the three studied properties, represented by the value of the fisher test (f-value), the $p$-value and the $\mathrm{r}^{2}$ adjustment coefficient. The effects $\mathrm{x}_{2} \mathrm{x}_{4}, \mathrm{x}_{3} \mathrm{x}_{4}, \mathrm{x}_{1} \mathrm{x}_{2} \mathrm{x}_{4}, \mathrm{x}_{1} \mathrm{x}_{3} \mathrm{x}_{4}$ and $\mathrm{x}_{2} \mathrm{x}_{3} \mathrm{x}_{4}$ could not be estimated because they are linear combinations of other effects.

Table 4: Results of the variance analysis (ANOVA) for the properties of the diaphragms.

\begin{tabular}{|c|c|c|c|c|}
\hline PROPERTIES & EQUATION & $\bar{F}$ & $p$ & $\overline{\mathbf{R}^{2}}$ \\
\hline $\mathbf{L}(\mathbf{c m})$ & $\begin{array}{c}\mathrm{L}=0.255 * \mathrm{X}_{1}+0.219 * \mathrm{X}_{2}+0.395 * \mathrm{X}_{3}+0.435 * \mathrm{X}_{4} \\
+2.621 * \mathrm{X}_{1} * \mathrm{X}_{2}+0.133 * \mathrm{X}_{1} * \mathrm{X}_{3}-1.210 * \mathrm{X}_{1} * \mathrm{X}_{4}-1.805 * \mathrm{X}_{2} * \mathrm{X}_{3}- \\
2.488 * \mathrm{X}_{1} * \mathrm{X}_{2} * \mathrm{X}_{3}\end{array}$ & 16.17 & $\begin{array}{l}0.19^{*} \\
*\end{array}$ & $\begin{array}{c}99.23 \\
\%\end{array}$ \\
\hline $\mathbf{K}\left(\mathbf{c m}^{2}\right)$ & $\begin{array}{c}\mathrm{Kx} 10^{8}=0.720 * \mathrm{X}_{1}+0.857 * \mathrm{X}_{2}+5.800 * \mathrm{X}_{3}+13.900 * \mathrm{X}_{4}+61.193 * \\
\mathrm{X}_{1} * \mathrm{X}_{2}-47.494 * \mathrm{X}_{1} * \mathrm{X}_{3}-23.118 * \mathrm{X}_{1} * \mathrm{X}_{4}-53.305 * \mathrm{X}_{2} * \mathrm{X}_{3}+248.776 * \\
\mathrm{X}_{1} * \mathrm{X}_{2} * \mathrm{X}_{3}\end{array}$ & 1040.9 & $\begin{array}{c}<0.00 \\
1 *\end{array}$ & $\begin{array}{c}99.99 \\
\%\end{array}$ \\
\hline$N_{m a c}$ & $\begin{array}{c}\text { Nmac }=1.125 * X_{1}+1.130 * X_{2}+1.17 * X_{3}+1.370 * X_{4}+0.685 * X_{1} * X_{2^{-}} \\
0.675 * X_{1} * X_{3}-0.907 * X_{1} * X_{4}-1.062 * X_{2} * X_{3}+9.200 * X_{1} * X_{2} * X_{3}\end{array}$ & 42.99 & $\begin{array}{c}<0.00 \\
1 *\end{array}$ & $\begin{array}{c}97.45 \\
\%\end{array}$ \\
\hline
\end{tabular}

* Significant to the level of $5 \%$ probability of error. $* *$ Not significant at the level of $5 \%$ error probability.

Although it offers an adjustment coefficient of $99.23 \%$, indicating that the model can explain $99.23 \%$ of the total variation around the average, the proposed model for the variable thickness is not statistically significant within the error probability of $5 \%(p>0.05)$, a significant analysis of the coefficients is necessary.

The pareto charts, shown in fig. 2, present the main effects and interactions of the independent variables with the thickness, permeability and resistivity for the special cubic model. The variable interactions have a confidence limit of $95 \%$, and, estimating the significance of the coefficients calculated for each model was possible based on this analysis.

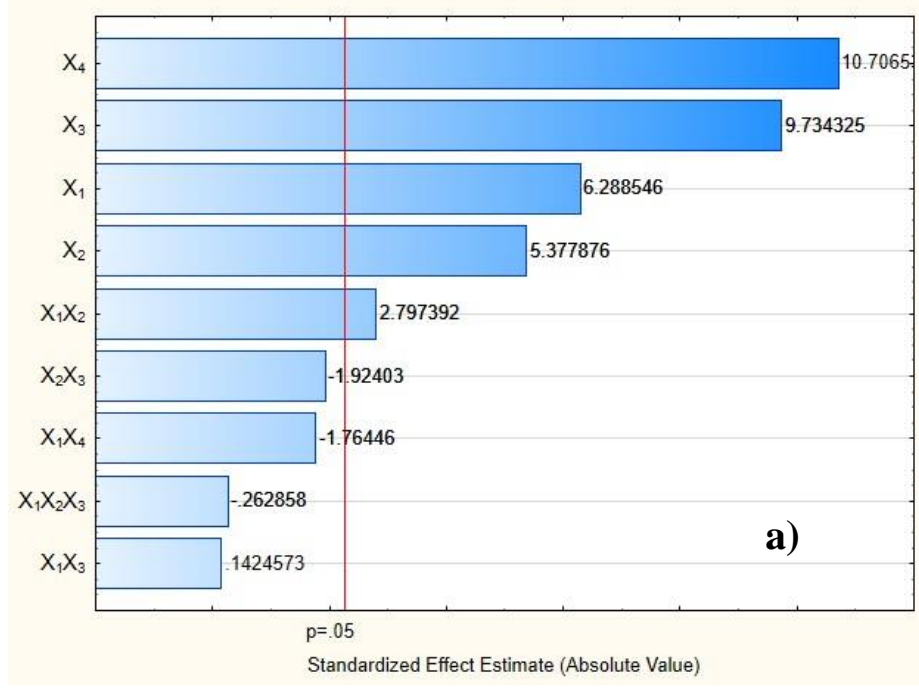



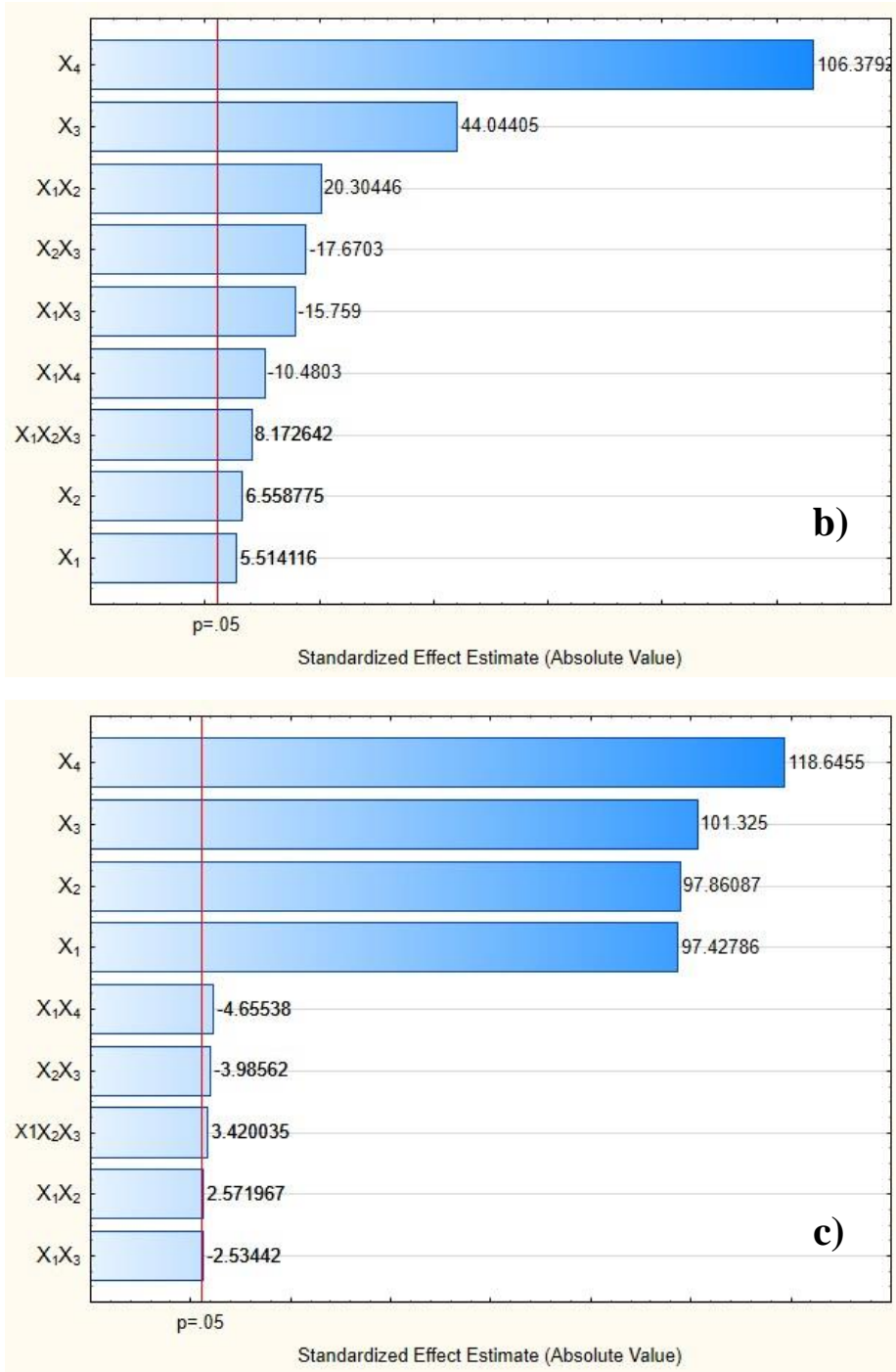

Figure 2: Pareto charts of the independent variables and their interactions: a) for thickness; b) for permeability and c) for resistivity.

As seen by analyzing fig. $2 \mathrm{a}$, only linear factors $\mathrm{X}_{1}, \mathrm{X}_{2}, \mathrm{X}_{3}$ and $\mathrm{X}_{4}$ have a significant effect on the thickness variable. Both have a positive factor, that is higher for MF78, meaning the greater the mass of this microfiber in the diaphragm composition, the greater the diaphragm's thickness will be. This is related to the fact that MF78 possesses the longest fiber length, which leads to higher packing of the fibers during their deposition on the cathode. This fact is evidenced by [20], who showed that an increase in the amount of long fibers in relation to the quantity of short fibers causes the thickness to increase and the packaging of the diaphragm to decrease. A high diaphragm thickness leads to a greater cell voltage, resulting in greater energy consumption in the process. In addition, the binary interaction between $\mathrm{X}_{1} \mathrm{X}_{2}$ presents a synergistic interaction that increases the thickness. Thus, taking only the significant effects into consideration, the cubic order model for the thickness can be estimated as:

$L=0.255 * X_{1}+0.218 * X_{2}+0.395 * X_{3}+0.435 * X_{4}+2.621 * X_{1} * X_{2}$

In Fig. 2b, according to the values of the " $t "$ test, the special cubic model was able to predict the linear relationship and the effects of the quadratic and cubic interaction on the permeability of the diaphragms. As in the thickness analysis, the parameter that presented the most significant influence on the permeability was MF78. This influence is related to the number of pores formed when longer fibers are deposited over the cathode. These pores lead to an increase in the percolation of the brine. The binary interactions $\mathrm{X}_{1} \mathrm{X}_{3}, \mathrm{X}_{1} \mathrm{X}_{4}$ and $\mathrm{X}_{2} \mathrm{X}_{3}$ result in a lower permeability than the estimated average values and lead to an antagonistic effect 
on the permeability. In other words, these interactions produce a decrease in the thickness of the diaphragm. The interaction $X_{1} X_{2}$ and $X_{1} X_{2} X_{3}$ promote a synergistic interaction, increasing the permeability of the diaphragm.

For resistivity, the magnitude of the parameters shown in Fig. 2c, give a significant positive result of the main effects on resistivity, and these resistivity effects are, more pronounced in the parameter MF78. The resistivity of the diaphragms is directly related to theirs thickness, and the analysis performed for thickness corroborates this fact. The binary interactions $\mathrm{X}_{1} \mathrm{X}_{3}, \mathrm{X}_{1} \mathrm{X}_{4}$ and $\mathrm{X}_{2} \mathrm{X}_{3}$ have an antagonistic effect, favoring a decrease in the resistivity of the diaphragms. This effect is more pronounced in the interaction between MF50 and MF78.

Since it is directly linked to the energy cost of the process, resistivity is an important variable, and a qualitative analysis of the effects of thickness and permeability on the resistivity of the diaphragm was complete. Considering the thickness and permeability as independent variables, a multiple linear regression was performed in order to estimate a mathematical model that explains the relationship between the thickness, permeability and resistivity.

Per the results of the ANOVA in Table 5, the model is useful for predicting the resistivity because its p-value from the $F$ test is much lower than the value of 0.05 of the error probability. The model can explain the $92.12 \%$ of the resistivity variability, thus proving the two variables are related to the resistivity of the diaphragms. The regression model is represented by Equation 5 .

$$
N_{\text {mac }}=1.15-0.1764 * L+0.0198 * K
$$

Table 5: Variance analysis of multiple linear regression.

\begin{tabular}{c|c|c|c|c|c}
\hline & gl & SQ & MQ & F & F OF SIGNIFICATION \\
\hline Regression & 2 & 0.086696 & 0.043348 & 87.69317 & $<<0.0001$ \\
\hline Residue & 15 & 0.007415 & 0.000494 & & \\
\hline Total & 17 & 0.094111 & & & \\
\hline
\end{tabular}

Figure 3 illustrates the surface graph to a linear regression of conductivity. Is possible to observe a direct relationship between the dependent variables with the conductivity, showing a negative correlation to the thickness and positive correlation to the permeability, presenting an adjust of data to the $\mathrm{R}^{2}$ model superior to $92 \%$. We can observe that the conductivity increases proportionally as the permeability of the diaphragm increases.

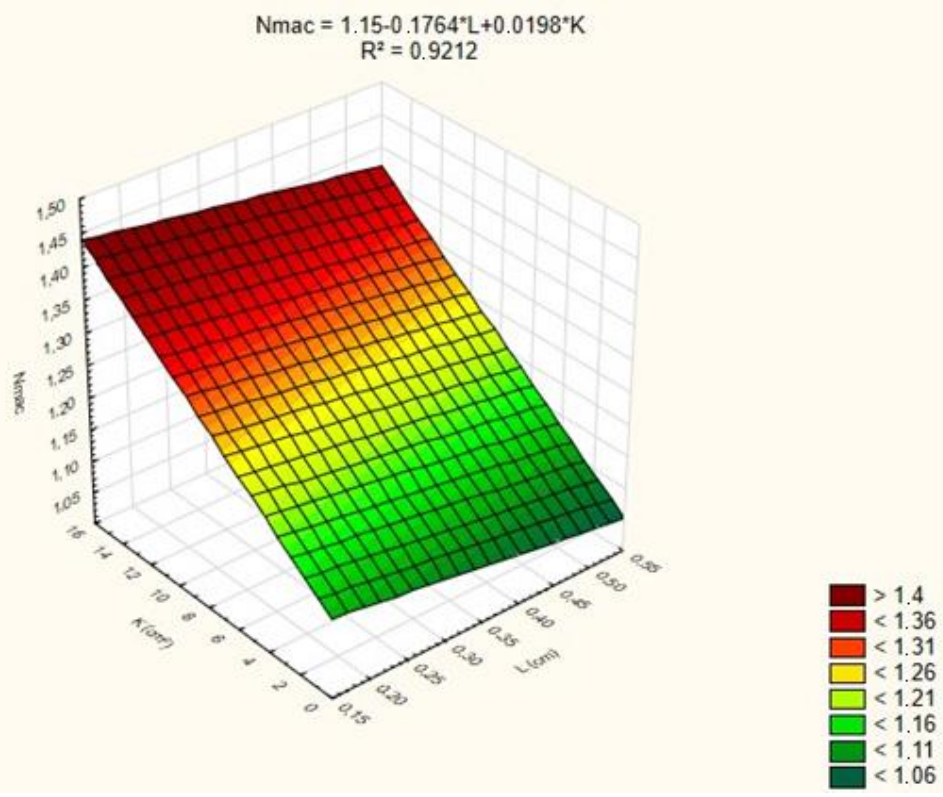

Figure 3: Surface graph of $\mathrm{N}_{\mathrm{mac}}$ versus permeability and thickness. 
In Figures $4 \mathrm{a}$ and $4 \mathrm{~b}$ we can observe the conductivity estimates as a function of thickness and permeability. When the parameters are evaluated individually, it is possible to notice a moderate correlation $(r=$ 0.58 ) between the thickness and the $\mathrm{N}_{\text {mac }}$ of the diaphragms, this parameter not being sufficient to determine the resistivity of the diaphragms. However, when we analyzed only the permeability, we observed a strong relationship between the permeability and resistivity data of the diaphragms $(r=0.98)$, that is, when we increase the permeability to a factor of $1 \mathrm{~cm}^{2}$, the resistivity of the diaphragm increases, on average, 0.01726 .

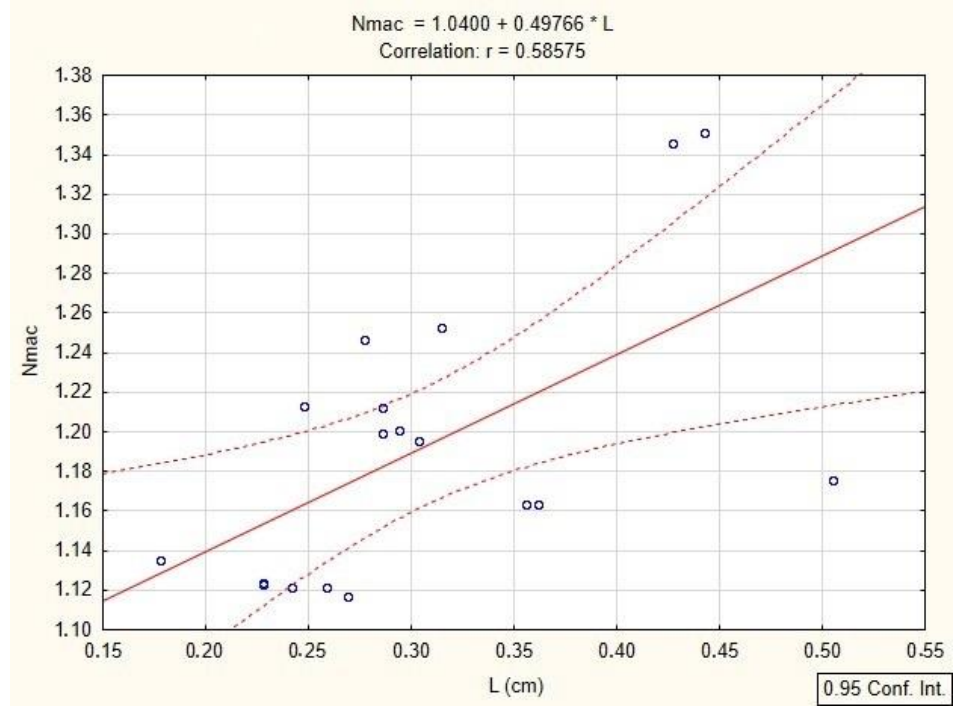

a)

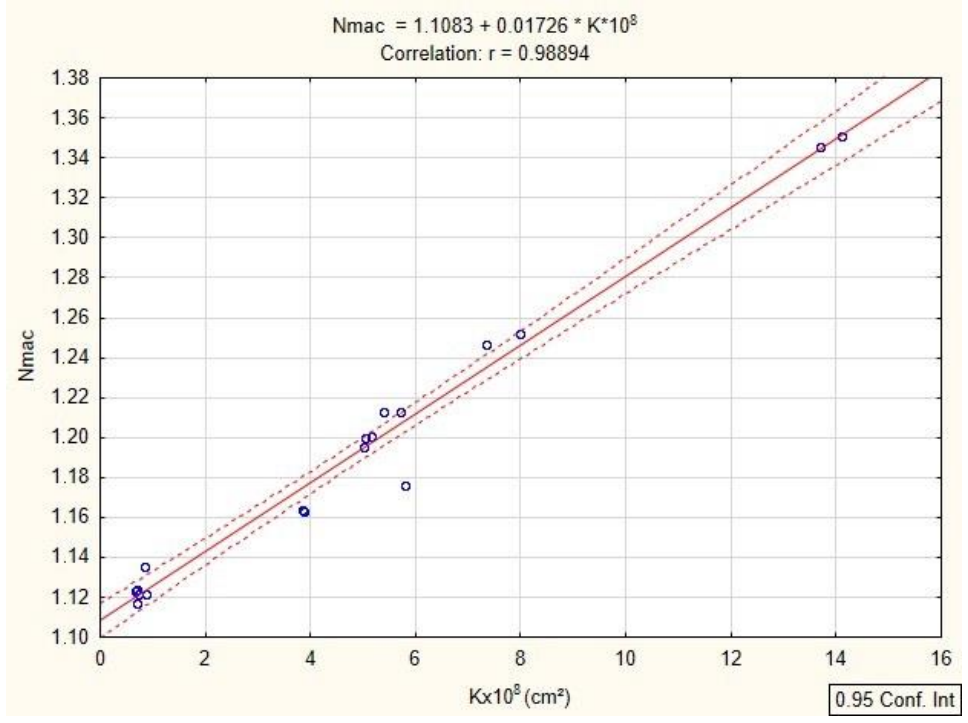

b)

Figure 4: Graph of resistivity as a function of the thickness and permeability constructed from the linear regression of the data obtained with the pure species: a) Thickness b) Permeability.

\section{CONCLUSIONS}

This study examined the application of the simples lattice mixture model in the development of diaphragms for use in the production of chlor-alkali. A strong relationship between the length of the fibers and diaphragm's properties was observed within this statistical analysis. The analysis showed that the smaller the fiber length was, the more effective the diaphragm's performance. Based on the multiple linear regression method, the correlation between the properties of the diaphragm could be explained. The model presented a correlation of $92.12 \%$. proving that the thickness and permeability of the diaphragm are directly related to the resistivity. 


\section{ACKNOWLEDGMENTS}

The authors thanks to CNPq and CAPES for their financial support of this work and the Electrochemical Engineering Laboratory of UFCG (LEEq/UFCG).

\section{BIBLIOGRAPHY}

[1] ANDRADE, J.E.P., ZAPORSKI, J., “A indústria de cloro-soda”, Revista do BNDS, v. 1, n.2, pp. 491-498.

[2] EUROCHLOR. Industry Review 2016-2017.

[3] HINE, F., O’BRIEN, T.F., BOMMARAJU, T.V., Handbook of chlor-alkali technology, Springer-New York, 2005.

[4] CALDWELL, D.L.,Tutorial Lectures in Electrochemical Engineering and Technology. R.C. Alkire e Der-Tau Chin, editors, 3, AIChE Symposium Series, 229: 79, 1983;

[5] ROMINE, R., Diaphgram cell technology, oxytech systems, Inc., Chardon, Ohio Usa, Presented at The Electrode Corp. Chlorine/Chlorate Seminar, São Paulo, 1977.

[6] DUBOIS, D.W., DILMORE, C.R., Diaphragm for use in chlor-alkali cells. United States Patent N. $5,192,401,1993$

[7] CURLIN, L.C. FLORKIEWICZ,T.F. MATOUSEK, R.C., "Polymarix: A depositable replacement for asbestos diaphragms", Modern Chlor-Alkali Technology, v.4, 334-335, 1990.

[8] KUNTZBURGER, F., HORBEZ, D., LEHELLOCO, J.G., et al. "New developments in built-in precathode diaphragm technology", Modem Chlor-Alkali Technology, v. 7,p. 181, 1998.

[9] CUNHA, C.T.C., Desenvolvimento e avaliação de diafragmas poliméricos para aplicação no processo de produção eletrolítica de cloro-soda. Thesis $\mathrm{PhD}$, Federal University of Campina Grande/CCT/UAEQ, Campina Grande- PB, Brazil, 2015.

[10] VIANA, K.M.S., VILAR, E.O., LIRA, H.L., et al. "Avaliação do desempenho do compósito amianto/polietileno durante a eletrólise da salmoura", Revista eletrônica de materiais e processos, v. 3, pp. 12-19, 2008.

[11] VIANA, K.M.S. Diafragmas de PEUAPM para aplicação no processo de produção eletrolítica de clorosoda. 2009. 113 f. Tese (Doutorado em Engenharia de Processos) - Universidade Federal de Campina Grande, Campina Grande, 2009.

[12] POUSH, K.A., CALDWELL, D.L., VAN ZEE, J., et al., 1983. "Characterization of asbestos diaphgrams for chlor-alkali electrolysis", Modern Chlor-Alkali Technology, 2, Edited by C. Jackson. Ellis Horwood Limited.

[13] GORMAN, J.W., HINMAN, J.E., 1962. "Simplex Lattice Designs for Multicomponent Systems", Technometrics, 4, 4, 463-487.

[14] CORNELL, J. “A.,Experiments with mixtures: A review”. Technometrics, v. 15, n. 3, pp. 437-455, 1973

[15] CORNELL, J.A., "Experiments with mixtures: Designs, models, and the analysis of misture data". John Wiley \& Sons, Inc. 3, 23, 1981.

[16] NUNES, D.B., Rotinas para otimização experimental de misturas, Dissertation Federal University of the Rio Grande do Sul, MsC, Porto Alegre-RS, Brazil, 1998

[17] SCHEFFÉ, H., 1958. Experiments with wixtures. Journal of the statistical society series b, 20, 344-360,

[18] LIMA, P.R., MIRAPALHETA, A., DOS SANTOS ANDRADE, M.H.; et al. "Energy loss in electrochemical diaphragm process of chlorine and alkali industry-A collateral effect of the undesirable generation of chlorate". doi: https://doi.org/10.1016/j.energy.2010.01.039. Energy, v. 35, n. 5, p. 2174-2178, 2010.

[19] CALDWELL, D.L., POUSH, K.A., WHITE, R.E., et al., Mathematical model of the chlorine cell diaphragm. Electrochemical Society $161^{\text {st }}$ Meeting. Montreal, Canadá, 1982.

[20] ALMEIDA FILHO, E.M., VILAR, E.O., FEITOZA, A.C.O., 2011. "Physical-chemical characterization and statistical modeling applied in a chlor-alkali diaphragm-cell process". Chemical Engineering Research and Design. 89, 491-498. 


\section{ORCID}

Celso Fidelis de Moura Junior Raquel Araújo Nunes

Rafael Teles Cruz Silva

Hélio de Lucena Lira

Carlos Thiago Cândido Cunha

Eudésio Oliveira Vilar https://orcid.org/0000-0002-9952-8360

https://orcid.org/0000-0002-6812-3010

https://orcid.org/0000-0003-4895-2556

https://orcid.org/0000-0002-1527-9935

https://orcid.org/0000-0002-8469-1798

https://orcid.org/0000-0002-8613-1938 